\title{
Clear Cell Sarcoma of Soft Tissue
}

National Cancer Institute

\section{Source}

National Cancer Institute. Clear Cell Sarcoma of Soft Tissue. NCI Thesaurus. Code C3745

A rare malignant neoplasm with melanocytic differentiation characterized by the presence of polygonal or spindle shaped clear cells. This sarcoma usually affects the tendons and aponeuroses and is associated with a poor prognosis due to recurrences and metastases. 